\title{
ANALISIS BREAK EVEN POINT PENJUALAN PUPUK KOMPOS TOAR ORGANIC FERTILIZER DI KAKASKASEN KOTA TOMOHON
}

\author{
Maya Basaria Sianipar \\ Juliana R. Mandei \\ Theodora M. Katiandagho
}

\begin{abstract}
The purpose of this study was to analyze the value of sales of compos at break even. Starting from of 2012, 2013, 2014 and 2015. Analysis of break even point is an analysis tools that is used by management of a company that serves to determine the level of sales, so the company doesn't profit and loss. Analysis of break even points can be used by a manager or a leader of the company with the aim to determine the level of sales volume before experiencing benefits and losses.Research uses the data analysis break even point. Research result shows that every year this business is able to obtain even a break even achieve a profit.
\end{abstract}

Keywords:break even point, compost, urban village of Kakaskasen, Tomohon City

\begin{abstract}
ABSTRAK
Tujuan dari penelitian ini adalah untuk menganalisis jumlah nilai penjualan pupuk kompos pada titik break even pada tahun 2012, 2013, 2014 dan 2015. Analisis break even point adalah suatu alat analisis yang digunakan oleh manajemen suatu perusahaan untuk mengetahui tingkat penjualan tertentu sehingga perusahaan tidak mengalami laba namun tidak mengalami rugi. Analisis break even point dapat digunakan manajer untuk mengetahui tingkat volume penjualan sebelum perusahaan mengalami untung dan mengalami rugi. Penelitian ini menggunakan analisis data break even point. Hasil penelitian ini menunjukkan bahwa setiap tahun usaha ini mampu memperoleh break even bahkan mencapai keuntungan setiap tahunnya.
\end{abstract}

Kata kunci: break even point, pupuk kompos. Kelurahan Kakaskasen, Kota Tomohon

\section{PENDAHULUAN}

\section{Latar Belakang}

Pola hidup sehat menjadi salah satu ukuran standar kualitas masyarakat modern. Pola hidup sehat bukan sekedar menyeimbangkan antara kesibukan dan olahraga, tetapi juga mengkonsumsi makanan. Semakin sedikit kandungan bahan kimia dalam suatu produk pangan, maka semakin kecil pula resiko mengalami berbagai gangguan penyakit. Masyarakat semakin menyadari semakin banyaknya bahan-bahan kimia dalam produk pertanian seperti, pupuk anorganik, pestisida anorganik dan hormon tumbuh sintesis. Hal ini membuat masyarakat untuk memilih pangan yang sehat. Perubahan pola pikir masyarakat terhadap pangan yang sehat menjadi titik tumpu terdorongnya pengembangan produksi pertanian organik di Indonesia untuk mendukung bertumbuhnya pangan organik.

Pangan organikadalah pangan yang bertumpu pada kaidah-kaidah teknik pertanian organik. Teknik pertanian organik adalah teknik budidaya yang mengandalkan bahanbahan alami tanpa menggunakan bahan-bahan kimia sintetis seperti penggunaan pupuk. Dalam teknik pertanian organik digunakan pupuk organik karena pada dasarnya pupuk adalah salah satu kebutuhan yang sangat vital bagi tanaman.

Pupuk organik memiliki peran sangat penting bagi kesuburan tanah dibandingkan pupuk anorganik. Pada dasarnya pupuk anorganik adalah pupuk yang jika digunakan dalam waktu yang lama akan menyebabkan kerusakan pada lahan pertanian. Pupuk organik memiliki banyak keuntungan dari segi ekologi dan ekonomis.Keuntungan pupuk organik 
secara ekologi adalah mampu memperbaikistruktur tanah yang rusak akibat dari pemakaian pupuk kimia, mengubah struktur tanah menjadi lebih baik sehingga pertumbuhan akar tanaman menjadi lebih baik, meningkatkan daya serap dan daya pegang tanah terhadap air sehingga tersedia cadangan air bagi tanaman dan memperbaiki kehidupan organisme tanah.

Keuntungan pupuk organik secara ekonomis adalah bahwa pupuk organik sangat mudah diperoleh dari alam sehingga modal pupuk organik jauh lebih murah dibandingkan modal pupuk anorganik. Pupuk organik terdiri dari beberapa jenis, yaitu : pupuk kandang, pupuk hijau, humus, kompos, dan pupuk organik lainnya. Pupuk kompos adalah salah satu alternatif yang bisa digunakan dikarenakan pupuk kompos dinilai lebih mudah diaplikasikan pada tanaman dan memberikan dampak yang positif bagi tanaman (Nugroho, 2013).

Industri usaha pupuk organik di Sulawesi Utara pada umumnya terdiri dari usaha kecil menengah dan bersifat parsial. Berdasarkan data dari Departemen Pertanian pada tahun 2015 bahwa kebutuhan pupuk organik di Sulawesi Utara sebesar 1.697 ton sedangkan ketersediaan pupuk organik pada tahun yang sama 951,86 ton.sebesar. Hal ini membuktikan bahwa kebutuhan pupuk organik di Sulawesi Utara masih belum terpenuhi karena ketersediaan pupuk organik masih relatif kecil.

Salah satu usaha pupuk kompos yang berkembang di Kota Tomohon adalah usaha pupuk kompos Toar organic fertilizer. Usaha pupuk kompos Toar organic fertilizerterbentuk pada tahun 2012 yang berlokasi di kakaskasen Kota Tomohon.Usaha pupuk kompos Toar organic fertilizer merupakan usaha kecil atau mikro yang bergerak di bidang pertanian. Usaha pupuk kompos ini merupakan usaha pupuk kompos yang mampu bertahan dibandingkan usaha pupuk kompos lainnya dikarenakan banyak usaha pupuk kompos di daerah kakaskasen yang sudah mengalami kolaps.

Di dalam bertahannya suatu usaha perlu digunakan suatu analisis ekonomi untuk mengetahui cara pengelolaan yang efisien agarusaha mampu mempertahankan ataupun meningkatkan produksinya.Pengelolaan berencana di dalam suatu usaha harus dilakukan untuk meningkatkan produksi dalam memenuhi permintaan pasar dan memperoleh keuntungan yang diharapkan. Untuk dapat bertahan hidup dan tumbuh menjadi lebih besar, dalam menjalankan kegiatannya maka usaha pupuk kompos Toar organic fertilizer harus menggunakan suatu analisis ekonomi yang mampu memberikan informasi bagaimana mengendalikan dan mempertimbangkan apa yang harus dilakukan dan direncanakan dalam menjalankan usaha ini agar tidak kolaps seperti usaha-usaha pupuk kompos. Dengan melihat kondisi usaha-usaha pupuk kompos yang sudah kolaps, maka usaha pupuk kompos Toar organic fertilizer harus seefisien mungkin dalam mengalokasikan dana dan membuat kebijakan bagi usahanya supaya dapat tetap bertahan. Suatu usaha kecil menengah harus mengetahui tingkat produksi dan penerimaan minimum, agar usaha tersebut dapat menutup semua biaya operasionalnya.

Dengan mengetahui hubungan antara jumlah pupuk kompos yang diproduksi, biaya yang digunakan dan harga jual pupuk di tahuntahun sebelumnya, maka usaha ini mampu mengambil keputusan dalam memproduksi pupuk kompos. Supaya dapat tetap eksis dalam usaha pupuk kompos dan dapat membuat kebijakanmengenai produksi, harga, dan biaya, maka analisis ekonomi yang bisa digunakan adalah analisis break even point atau analisis titik impas.Analisisini juga memudahkan pemilik usaha untuk mengambil keputusan dalam rangka menghadapi persaingan dengan produk sejenis.

Dengan menggunakan analisis break even pointpada penjualan ditahun sebelumnya diharapkan usaha ini mampu mengambil keputusan untuk memproduksi pupuk kompos di tahun yang akan datang dan memperoleh laba yang diharapkan.

\section{Perumusan Masalah}

Berdasarkan uraian latar belakang di atas maka yang menjadi masalah dalam penelitian ini adalah berapa besar jumlah dan nilai penjualan usaha pupuk kompos Toar organic fertilizer pada titik break even point? 


\section{Tujuan Penelitian}

Untuk menganalisis jumlah nilai penjualan usaha pupuk kompos Toar organic fertilizer padabreak even point.

\section{Manfaat Penelitian}

a. Bagi Penulis

Dapat menambah pengetahuan dan pengalaman serta dapat dijadikan perbandingan dari teori-teori yang didapat di perkuliahan khususnya mengenai analisis break even point dengan penelitian langsung pada usaha pupuk kompos Toar organic fertilizer.

b. Bagi Perusahaan

Dapat dijadikan sebagai bahan masukan dan informasi yang dapat digunakan sebagai pengukuran keadaan usaha selama menjalankan kegiatan operasional, apakah usaha pupuk kompos berada pada break even point.

c. Pihak Lain

Dapat digunakan sebagai bahan informasi dan perbandingan bagi pihak lain atau penulis lainnya yang teori pembahasannya mengenai analisis break even point.

\section{METODOLOGI PENELITIAN}

\section{Waktu dan Tempat Penelitian}

Pengambilan data dilakukan pada bulan April sampai dengan bulan Mei 2016 bertempat di kelurahan Kakaskasen, Kota Tomohon, Provinsi Sulawesi Utara. Pemilihan daerah penelitian dilakukan secara sengaja (Purposive) dengan alasan usaha pupuk kompos Toar Organic Fertizer merupakan usaha pupuk kompos yang mampu bertahan dibandingkan usaha pupuk kompos yang sudah koleps. Penduduk di kelurahan kakaskasen ini sebagian besar bermatapencarian sebagai petani sehingga limbah-limbah pertanian dapat digunakan sebagai bahan baku pembuatan kompos.

\section{Jenis dan Sumber Data}

Data yang digunakan dalam penelitan ini merupakan data primer dan data sekunder. Data primer berupa pengamatan langsung ke lapangan dengan metode wawancara langsung dengan responden. Responden yang dipilih adalah pemilik dari usaha pupuk kompos Toar
Fertilizer Organic. Data sekunder diperoleh dari studi literatur, buku, makalah, penelitian terdahulu, internet dan informasi dari berbagai instansi terkait seperti Badan Pusat Statistik Kota Tomohon dan Kementerian Pertanian.

\section{Metode Pengumpulan Data}

Data dan informasi dikumpulkan untuk memperoleh suatu gambaran yang berkaitan dengan lingkup usaha. Pengumpulan data primer diperoleh pada saat turun lapangan ke lokasi penelitian yaitu usaha pupuk kompos Toar FertilizerOrganic di Kelurahaan Kakaskasen. Metode yang digunakan untuk pengumpulan data primer berupa wawancara langsung dengan menggunakan kuesioner terbuka serta observasi. Lokasi pengumpulan data sekunder meliputi instansi yang terkait seperti, kantor Lurah Kakaskasen.

\section{Konsepsi dan Pengukuran Variabel}

Periode data yang digunakan dalam peneitian ini adalah data selama empat tahun yaitu dari tahun 2012 - 2015. Variabel-variabel yang diukur dalam penelitian ini adalah :

1. Volume produksi yaitu jumlah produksi pupuk kompos per tahun $(\mathrm{Kg})$.

2. Penerimaan dan hasil penjualan ( $\mathrm{Rp})$.

Total penerimaan selama satu tahun, yaitu harga dikalikan dengan volume penjualan.

3. Harga jual pupuk kompos $(\mathrm{Rp} / \mathrm{kg})$.

4. Biaya produksi yaitu biaya tetap dan biaya variabel selama satu tahun.

a. Biaya Tetap

- Biaya penyusutan peralatan (Rp) yaitu biaya yang harus dikeluarkan karena terjadinya penurunan nilai dari peralatan yang digunakan.

- Biaya Kredit Bank (Rp) yaitu biaya pinjaman yang harus dibayar kepada Bank.

b. Biaya Variabel

- Biaya bahan baku: jerami padi, sekam padi dan kotoran ternak (Rp/tahun)

- Biaya bahan bakar (Rp/tahun)

- Biaya tenaga kerja (Rp/tahun)

- Biaya pemasaran : semua pengeluaran dalam proses penyaluran produk-produk pupuk kompos dari pemilik ke produsen (toko-toko pertanian)

- Biaya kemasan (Rp/tahun)

- Biaya pemeliharaan (Rp/tahun). 


\section{Metode Analisis Data}

Penelitian ini menggunakan penelitian deskriptif dengan menggunakan pendekatan kuantitatif karena penelitian ini menggambarkan keadaan usaha pupuk kompos Toar Organic Fertilizer pada saat mencapai break even point. Rumus yang digunakan untuk mengkaji analisis data adalah sebagai berikut:

1. Untuk mengetahui pada titik berapa usaha ini akan mengalami break even point pada produk tunggal

$\mathrm{BEP}$ (unit) =

Total biaya tetap

Harga jual per unit - Biaya variabel per unit

$\mathrm{BEP}($ rupiah $)=\frac{\text { Total biaya tetap }}{1-\frac{\text { Biaya variabel per unit }}{\text { Harga jual }}}$

2. Untuk mengetahui pada titik berapa usaha ini akan mengalami break even point untuk lebih dari satu jenis produk atau sales mix.

Break Even Keseluruhan =

$\frac{\text { Biaya Tetap }}{1-\frac{\text { Biaya Variabel }}{\text { Penerimaan Total }}}$
Break Even per Unit $=$
$\frac{\text { Break Even Keseleruhan }}{\text { Penerimaan Total }} \times$ Jumlah Unit

\section{HASIL DAN PEMBAHASAN}

\section{Deskripsi Umum Usaha Toar Organic Fertilizer}

Usaha Toar Organic Fertilizer merupakan jenis usaha mikro yang bergerak dalam usaha pembuatan pupuk kompos yang yang berasal dari jerami padi dan kotoran ternak yang dicampurkan. Usaha Toar Organic Fertilizer ini berlokasi di Kelurahan Kakaskasen II di Kota Tomohon. Pemilik Usaha Toar Organic Fertilizer adalah Bapak Toar Malingkas yang merupakan dosen dari Fakultas Pertanian Universitas Sam Ratulangi. Usaha ini berawal dari adanya program Pemerintah yang sangat booming pada tahun 2010 yaitu Back to Nature.

Berdasarkan penelitian pada usaha Toar Organic Fertilizer, untuk keseluruhan usahanya digunakan tenaga kerja tetap satu orang dimana tenaga kerja tetap ini adalah rekan yang menjadi partner kerja dari pemilik dan tenaga kerja tidak tetapadalah dua orang. Bahan baku yang digunakan dalam produksi ini yaitu jerami padi dan kotoran ternak yang diambil dari daerah Minahasa Utara. Kegiatan produksi yang dilakukan usaha ini adalah dua kali dalam satu tahun, dengan jenis produk pupuk kompos yang dikemas dalam dua bentuk yaitu kemasan $5 \mathrm{~kg}$ dan kemasan $20 \mathrm{~kg}$. Dan semua produk yang dihasilkan dalam setiap kali produksi habis terjual karena usaha ini berproduksi setiap kali ada permintaan dan selama usaha ini berdiri permintaan yang diterima dari toko-toko pertanian selalu dua kali dalam setahun.

\section{Proses Produksi Pupuk Kompos}

Proses produksi pupuk kompos pada dasarnya dapat dibuat dari berbagai bahan organik, misalkan sampah organik seperti daundaunan, buah-buahan dan sisa sampah rumah tangga ataupun sisa hasil pertanian lainnya. Sampah yang tidak bisa membusuk seperti plastik dan logam tidak bisa dibuat kompos. Proses pembuatan kompos biasanya dibantu mikrobia yang mampu mempercepat proses

pembusukan. Proses pembuatan kompos aerob dilakukan di tempat terbuka dengan sirkulasi udara yang baik.

Langkah pertama dalam proses pembuatan pupuk kompos adalah persiapan bahan baku. Bahan baku yang digunakan adalah campuran sisa-sisa jerami padi dan kotoran hewan dengan bantuan mikroba untuk mempercepat proses pembusukan. Pembuatan kompos aerob memakan waktu 40 - 50 hari, suhu dan kelembapan kompos selama proses pengomposan berlangsung harus dikontrol. Proses pembuatan kompos aerob dilakukan di tempat terbuka dengan sirkulasi udara yang baik.

Proses pertama adalah pengumpulan bahan baku. Bahan baku yang diperoleh oleh pemilik adalah dari daerah sekitar karena derah proses pembuatan kompos berada di daerah pertanian. Setalah bahan baku dikumpulkan, maka bahan baku harus dicacah untuk proses pencampuran dengan larutan bio-aktivator (mikroba pembantu proses pembususkan). Setelah bahan baku dicacah dan dicampur dengan bio-aktivator kemudian dimasukkan ke wadah kering dan tertutup lalu biarkan selama satu minggu. Setelah satu minggu kemudian kompos yang sudah setengah jadi dibalik atau diaduk kemudian dibiarkan lagi selama satu 
minggu. Setelah satu minggu kompos dibalik lagi atau diaduk dan dibiarkan hingga matang selama satu minggu. Kemudian kompos dikeringkan ditempat yang teduh setelah kompos kering maka kompos diayak agar mendapat ukuran yang seragam. Setelah diayak maka kompos siap digunakan dan dikemas dalam dua bentuk kemasan yaitu kemasan $5 \mathrm{~kg}$ dan kemasan $20 \mathrm{~kg}$. Setelah selesai dikemas maka kompos akan dipasarkan ke toko-toko pertanian yang berada di daerah Tomohon dan minahasa utara.

Proses produksi untuk menjadi pupuk kompos dari bahan baku hingga siap jual pada toko-toko pertanian adalah sebagai berikut:

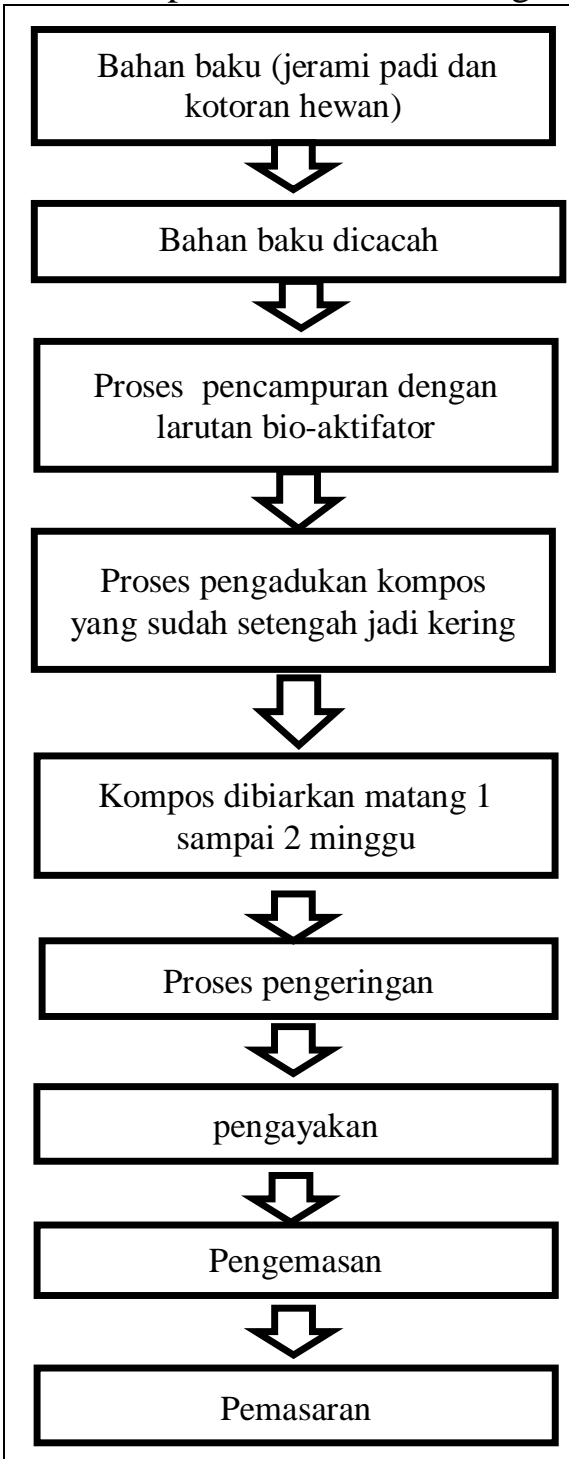

Gambar 3. Skema Proses Produksi Pupuk Kompos Toar Organic Fertilizer

\section{Volume Produksi dan Harga Jual}

Produksi adalah suatu proses mengubah input menjadi output sehingga nilai dari barang tersebut bertambah. Kegiatan produksi pupuk kompos Toar Organic Fertilizer dilakukan setiap empat bulan sekali atau dalam satu tahun dua kali produksi. Pada tahun pertama dan kedua usaha pupuk kompos Toar memproduksi pupuk sebanyak $20.000 \mathrm{~kg}$ dan tahun ketiga sampai tahun keempat usaha ini mengurangi produksinya dikarenakan kenaikan biaya bahan baku pada tahun 2014 yaitu $18.000 \mathrm{~kg}$ pupuk kompos. Pupuk kompos yang diproduksi dibagi dalam dua bentuk kemasan, yaitu kemasan 5 kilogram dan kemasan $20 \mathrm{~kg}$. Volume produksi pupuk kompos yang dihasilkan selama empat tahun. volume produksi yang dihasilkan usaha pupuk kompos Toar Organic Fertilizer pada tahun 2012 - 2013 adalah $20.000 \mathrm{~kg}$ pada kemasan lima kilogram adalah 200 bungkus plastik ( $1000 \mathrm{~kg}$ ) dan kemasan $20 \mathrm{~kg}$ adalah 950 karung $(19.000 \mathrm{~kg})$ sedangkan pada tahun 2014 - 2015 volume produksi usaha pupuk kompos menjadi $18.000 \mathrm{~kg}$.

Harga jual pupuk kompos berbeda-beda menurut beratnya. Pupuk kompos yang dikemas dalam kemasan lima kilogram lebih murah dibandingkan pupuk kompos kemasan $20 \mathrm{~kg}$. Harga jual pupuk kompos dapat dilihat pada Tabel 3. Tabel 3 menjelaskan bahwa harga jual pupuk kompos pada kemasan lima kilogram sebesar Rp. 15.000 pada tahun 2012-2013 dan pada tahun 2014-2015 sebesar Rp. 17.000 sedangkan kemasan $20 \mathrm{~kg}$ tahun 2012-2013 sebesar Rp. 60.000 dan tahun 2013-2014 sebesar Rp. 68.000. Pada tahun ketiga pemilik menaikan harga sebesar Rp. 400 sehingga harga jual pupuk kompos per kemasan mengalami kenaikan dikarenakan harga bahan baku yang meningkat

\section{Penerimaan}

Penerimaan (TR) adalah hasil kali antara harga per unit $(\mathrm{P})$ dan jumlah total produksi yang terjual (Q). Total penerimaan usaha pupuk kompos Toar OrganicFertilizer pada tahun 2012 dan 2013 adalah Rp. $\quad 60.000 .000$ sedangkan pada tahun 2014 dan 2015 total penerimaan mengalami peningkatan yaitu $\mathrm{Rp}$. 61.200.000. Hal ini dapat dilihat pada tabel 4 . 
Tabel 1. Volume Produksi Pupuk Kompos

\begin{tabular}{cccc}
\hline \multirow{2}{*}{ Tahun } & \multicolumn{2}{c}{ Jenis Kemasan (Bungkus) } & \multirow{2}{*}{ Jumlah (Kg) } \\
\cline { 2 - 3 } & $\mathbf{5 ~ K g}$ & $\mathbf{2 0 ~ K g}$ & 20.000 \\
2012 & 200 & 950 & 20.000 \\
2013 & 200 & 950 & 18.000 \\
2014 & 72 & 882 & 18.000 \\
2015 & 72 & 882 & \\
\hline
\end{tabular}

Sumber: Data Primer, 2015. Diolah

Tabel 2. Harga Jual Pupuk Kompos

\begin{tabular}{ccc}
\hline Tahun & \multicolumn{2}{c}{ Harga jual (Rp) } \\
\cline { 2 - 3 } & Kemasan 5 kg & Kemasan 20 kg \\
\hline 2012 & 15.000 & 60.000 \\
2013 & 15.000 & 60.000 \\
2014 & 17.000 & 68.000 \\
2015 & 17.000 & 68.000 \\
\hline
\end{tabular}

Sumber: Data Primer, 2015. Diolah

Tabel 3. Penerimaan Produksi Pupuk Kompos Selama Empat Tahun

\begin{tabular}{|c|c|c|c|c|c|c|c|}
\hline \multirow[b]{2}{*}{ Tahun } & \multicolumn{3}{|c|}{ Kemasan 5 Kg } & \multicolumn{3}{|c|}{ Kemesan 20 Kg } & \multirow{2}{*}{$\begin{array}{c}\text { Total } \\
\text { Penerimaan }\end{array}$} \\
\hline & $\begin{array}{c}\text { Jumlah } \\
\text { (unit) }\end{array}$ & $\begin{array}{c}\text { Harga } \\
(\mathbf{R p})\end{array}$ & Penerimaan & $\begin{array}{c}\text { Jumlah } \\
\text { (unit) }\end{array}$ & $\begin{array}{c}\text { Harga } \\
(\mathbf{R p})\end{array}$ & Penerimaan & \\
\hline 2012 & 200 & 15.000 & 3.000 .000 & 950 & 60.000 & 57.000 .000 & 60.000 .000 \\
\hline 2013 & 200 & 15.000 & 3.000 .000 & 950 & 60.000 & 57.000 .000 & 60.000 .000 \\
\hline 2014 & 72 & 17.000 & 1.224 .000 & 882 & 68.000 & 59.976 .000 & 61.200 .000 \\
\hline 2015 & 72 & 17.000 & 1.224 .000 & 882 & 68.000 & 59.976 .000 & 61.200 .000 \\
\hline
\end{tabular}

Sumber: Data Primer, 2015. Diolah

\section{Tabel 4. Penerimaan Produksi Pupuk Kompos Selama Empat Tahun}

Tahun Kemasan $5 \mathrm{Kg} \quad$ Kemesan $20 \mathrm{Kg}$

\begin{tabular}{cccccccc}
\hline & $\begin{array}{c}\text { Jumlah } \\
\text { (unit) }\end{array}$ & $\begin{array}{c}\text { Harga } \\
(\mathrm{Rp})\end{array}$ & Penerimaan & $\begin{array}{c}\text { Jumlah } \\
\text { (unit) }\end{array}$ & $\begin{array}{c}\text { Harga } \\
(\mathrm{Rp})\end{array}$ & Penerimaan & $\begin{array}{c}\text { Total } \\
\text { Penerimaan }\end{array}$ \\
\hline 2012 & 200 & 15.000 & 3.000 .000 & 950 & 60.000 & 57.000 .000 & 60.000 .000 \\
\hline 2013 & 200 & 15.000 & 3.000 .000 & 950 & 60.000 & 57.000 .000 & 60.000 .000 \\
\hline 2014 & 72 & 17.000 & 1.224 .000 & 882 & 68.000 & 59.976 .000 & 61.200 .000 \\
\hline 2015 & 72 & 17.000 & 1.224 .000 & 882 & 68.000 & 59.976 .000 & 61.200 .000
\end{tabular}

Sumber: Data Primer, 2015. Diolah

Tabel 4 menunjukkan bahwa penerimaan pupuk kompos mengalami kenaikan sebesar Rp. 1.200.000 pada tahun ketiga, hal ini dikarenakan pemilik menaikkan harga per kilogram pupuk kompos.

\section{Biaya Tetap}

Biaya tetap merupakan besarnya biaya yang harus dikeluarkan oleh perusahaan yang jumlahnya tetap, tidak bergantung pada besar kecilnya jumlah produk yang dihasilkan (Surjadi, 2013). Jenis-jenis biaya tetap yang 
dikeluarkan oleh usaha pupuk kompos Toar Organic Fertilizer adalah biaya penyusutan peralatan, biaya penyusutan kendaraan dan kredit bank.

\section{Biaya Penyusutan Peralatan}

Penyusutan adalah berkurangnya nilai dari aktiva tetap selama masa pakai. Biaya penyusutan yang ditetapkan oleh perusahaan dipengaruhi oleh harga perolehan atau sering disebut harga beli, umur ekonomis dan nilai residu . Dalam proses produksi pupuk kompos digunakan beberapa jenis alat seperti, cangkul, tong, jerigen, gerobak, terpal, sekop, corong, gayung, sprayer dan timbangan. Peralatan-peralatan ini mengalami penyusutan seiring dengan lamanya peralatan ini digunakan. Pada tabel 4 dapat dilihat harga beli, umur ekonomis, nilai sisa barang dan penyusutan per tahun.

\section{Biaya Penyusutan Kendaraan}

Usaha pupuk kompos Toar Organic memiliki kendaraan yaitu mobil yang merupakan kendaraan yang digunakan untuk memasarkan pupuk kompos ke toko-toko pertanian. Namun, pada tahun 2013 mobil mengalami kerusakan sehingga usaha ini menyewa mobil untuk memasarkan pupuk kompos ke toko-toko pertanian, maka pada tahun 2013 biaya penyusutan adalah biaya kerusakan mobil yaitu sebesar Rp. 5.400.000.

\section{Biaya Bunga Bank}

Dalam memulai usaha pupuk kompos pemilik melakukan pinjaman di bank sebesar Rp. 21.600.000 dan dilunasi selama empat tahun sehingga biaya kredit yang dikeluarkan per bulan adalah Rp. 1.800.000 sehingga dalam satu tahun biaya yang dikeluarkan untuk membayar kredit Bank adalah Rp. 21.600.000. Total biaya tetap yang dikeluarkan untuk memproduksi pupuk kompos selama satu tahun dapat dilihat pada Tabel 5.

Tabel 5. Peralatan Yang Digunakan Dalam Produksi Pupuk Kompos

\begin{tabular}{cccccc}
\hline Jenis peralatan & $\begin{array}{c}\text { Jumlah } \\
\text { (unit) }\end{array}$ & $\begin{array}{c}\text { Harga beli } \\
\text { per unit (Rp) }\end{array}$ & $\begin{array}{c}\text { Umur } \\
\text { Ekonomis } \\
\text { (Tahun) }\end{array}$ & Nilai sisa & $\begin{array}{c}\text { Penyusutan per } \\
\text { tahun (Rp) }\end{array}$ \\
\hline Cangkul & 2 & 75.000 & 2 & 7.500 & 67.500 \\
Tong & 2 & 170.000 & 10 & 17.000 & 30.600 \\
Jerigen & 10 & 40.000 & 4 & 4.000 & 90.000 \\
Terpal (8x10) $\mathrm{m}$ & 4 & 250.000 & 3 & 25.000 & 300.000 \\
Corong & 2 & 15.000 & 6 & 1.500 & 4.500 \\
Gayung & 2 & 10.000 & 3 & 1.000 & 6.000 \\
Sprayer & 4 & 1.800 .000 & 10 & 180.000 & 648.000 \\
Timbangan $(25$ & 1 & 200.000 & 10 & 20.000 & 18.000 \\
$\quad$ kg) & & & & & \\
Sekop & 2 & 55.000 & 5 & 5.500 & 19.800 \\
Gerobak & 2 & 250.000 & 10 & 25.000 & 45.000 \\
\hline Total & & & & 1.229 .400 & \\
\hline Sumber
\end{tabular}

Sumber: Data Primer, 2015. Diolah

Tabel 6. Biaya Penyusutan Kendaraan

\begin{tabular}{|c|c|c|c|c|c|}
\hline $\begin{array}{c}\text { Jenis } \\
\text { peralatan }\end{array}$ & $\begin{array}{c}\text { Jumlah } \\
\text { (unit) }\end{array}$ & $\begin{array}{l}\text { Harga beli per } \\
\text { unit (Rp) }\end{array}$ & $\begin{array}{c}\text { Umur } \\
\text { Ekonomis } \\
\text { (Tahun) }\end{array}$ & Nilai sisa & $\begin{array}{l}\text { Penyusutan per } \\
\text { tahun (Rp) }\end{array}$ \\
\hline Mobil & 1 & 75.000 .000 & 8 & 7.500 .000 & 8.437 .500 \\
\hline & \multicolumn{4}{|c|}{ Total } & 8.437 .500 \\
\hline
\end{tabular}

Sumber: Data Primer, 2015. Diolah 


\section{Biaya Variabel}

Biaya variabel adalah biaya yang berubah sesuai dengan volume produksi yang dihasilkan. Jumlah nilai dan komposisinya ditentukan untuk satu kali proses produksi.

\section{Biaya bahan baku}

Bahan baku yang digunakan dalam proses produksi pupuk kompos adalah jerami padi dan kotoran hewan dan bakteri bioaktivator pengurai kompos. Biaya bahan baku yang dikeluarkan selama satu tahun pada tahun 2012 dan 2013 adalah Rp. 4.500 .000 sedangkan pada tahun 2014-2015 biaya bahan baku mengalami kenaikan yaitu 5.500.000.

\section{Upah tenaga kerja}

Usaha pupuk kompos Toar Organic Fertilizer menggunakan dua orang tenaga kerja untuk setiap kali produksi dimana dalam satu tahun usaha ini melakukan dua kali proses produksi. Untuk proses pengambilan bahan baku dari sumber dan proses pengolahan selama satu tahun upah tenaga kerja adalah sebesar Rp. 2.000.000/orang. Namun pada tahun 2015 tenaga kerja mendapatkan kenaikan gaji menjadi Rp. 2.300.000/orang. Tenaga kerja juga memperoleh upah dari proses pemasaran.Dalam satu kali proses produksi dilakukan 10 kali pemasaran dimana upah yang diterima tenaga kerja untuk setiap kali pemasaran adalah Rp. 50.000 maka upah yang diperoleh tenaga kerja dalam proses pemasaran selama satu tahun adalah Rp. 2.000.000/orang.

\section{Biaya pemasaran}

Hasil produksi pupuk kompos Toar Organic Fertilizer dipasarkan ke toko-toko pertanian yang ada di daerah Tomohon dan Minahasa Utara. Biaya pemasaran yang dikeluarkan usaha ini setiap kali pemasaran adalah Rp.150.000, dimana dalam dalam satu tahun usaha ini melakukan pemasaran sebanyak 20 kali pemasaran sehingga dalam satu tahun biaya pemasaran sebesar Rp. 3.000.000. Namun, pada tahun 2013 mobil mengalami kerusakan sehingga biaya pemasaran yang dikeluarkan bertambah yaitu Rp. 310.000 dimana biaya tersebut merupakan biaya sewa mobil dan bahan bakar sehingga total biaya pemasaran selama setahun yaitu Rp. 6.210.000.

\section{Biaya kemasan}

Pengemasan pupuk kompos dibagi dalam dua jenis yaitu ukuran $5 \mathrm{~kg}$ menggunakan plastik sedangkan ukuran $20 \mathrm{~kg}$ menggunakan karung. Biaya yang digunakan untuk kemasan dapat dilihat pada Tabel 7.

Tabel 7 menunjukkan bahwa biaya kemasan pupuk kompos dalam kemasan plastik $5 \mathrm{~kg}$ pada tahun 2012 - 2013 adalah Rp. 800.000 karena pada tahun tersebut produksi pupuk kompos kemasan $5 \mathrm{~kg}$ adalah 200 bungkus plastik sedangkan biaya kemasan 20 kg adalah Rp. 5.700.000. Pada tahun $2014-$ 2015 usaha pupuk kompos mengurangi jumlah produksi pupuk kompus dikarenakan usaha ini menyesuaikan permintaan pasar terhadap produknya sehingga biaya kemasan untuk ukuran $5 \mathrm{~kg}$ adalah Rp. 280.000 dan kemasan $20 \mathrm{~kg}$ adalah Rp. 5.292.000. Total biaya pengemasan tahun 2012 dan 2013 adalah Rp. 6.500.000 dan pada tahun 2014 dan 2015 adalah Rp. 5.572.000.

\section{Biaya Bahan bakar}

Biaya bahan bakar adalah biaya yang dikeluarkan untuk mengambil bahan baku dari lokasi pengambilan sampai ke lokasi pembuatan kompos. Pengambilan bahan baku sebanyak empat kali dalam setiap kali proses produksi, dalam satu tahun proses produksi yang dilakukan adalah dua kali maka ditotal dalam satu tahun usaha ini melakukan delapan kali

\begin{tabular}{cccccc}
\hline \multicolumn{5}{c}{ Tabel 7. Biaya pengemasan selama empat tahun } \\
\cline { 3 - 6 } Jenis kemasan & $\begin{array}{c}\text { Harga per } \\
\text { unit (Rp) }\end{array}$ & $\mathbf{2 0 1 2}$ & $\mathbf{2 0 1 3}$ & $\mathbf{2 0 1 4}$ & $\mathbf{2 0 1 5}$ \\
\hline Kemasan 5 kg & 4.000 & 800.000 & 800.000 & 280.000 & 280.000 \\
Kemasan $20 \mathrm{~kg}$ & & & & & \\
& 6.000 & 5.700 .000 & 5.700 .000 & 5.292 .000 & 5.292 .000 \\
\hline & Total & 6.500 .000 & 6.500 .000 & 5.572 .000 & 5.572 .000 \\
\hline
\end{tabular}

Sumber: Data Primer, 2015. Diolah 


\begin{tabular}{|c|c|c|c|c|}
\hline \multicolumn{5}{|c|}{$\begin{array}{c}\text { Tabel 9. Rekapitulasi Break Even Point Penjualan Pupuk Kompos Toar } \\
\text { Organic Fertilizer untuk Produk Tunggal kemasan } 5 \text { kg }\end{array}$} \\
\hline Keterangan & 2012 & 2013 & 2014 & 2015 \\
\hline Biaya Tetap & 31.266 .900 & 28.229 .400 & 31.266 .900 & 31.266 .900 \\
\hline Biaya Variabel & 18.760 .000 & 20.260 .000 & 18.060 .000 & 18.860 .000 \\
\hline $\begin{array}{l}\text { Biaya Variabel per } \\
\mathrm{kg}\end{array}$ & 4.390 & 5.065 & 4.515 & 4.715 \\
\hline Harga Jual per unit & 15.000 & 15.000 & 17.000 & 17.000 \\
\hline $\begin{array}{l}\text { Total Produksi per } \\
\text { unit }\end{array}$ & 4.000 & 4.000 & 3.600 & 3.600 \\
\hline Penerimaan & 60.000 .000 & 60.000 .000 & 61.200 .000 & 61.200 .000 \\
\hline BEP (per kg) & 3.041 & 2.841 & 2.982 & 3.040 \\
\hline BEP (rupiah) & 44.205 .995 & 42.623 .283 & 44.730 .901 & 45.598 .512 \\
\hline Keuntungan & 15.794 .005 & 17.376 .717 & 16.469 .099 & 15.601 .488 \\
\hline
\end{tabular}

pengambilan bahan baku. Biaya yang dikeluarkan untuk satu kali pengambilan bahan baku adalah Rp. 100.000, namun pada tahun 2014 pemerintah menaikan harga BBM sehingga biaya bahan bakar mengalami kenaikan sebesar Rp. 75.000.

Biaya pemeliharaan
Biaya untuk oli mobil Rp. 360.000 per dua bulan maka biaya yang pemiliharaan selama satu tahun Rp. 2.160.000.

Analisis break even dimulai dengan mengklasifikasi biaya ke dalam biaya tetap dan biaya variabel. Tabel di bawah ini menggambarkan pengklasifikasian biaya-biaya dari tahun 2012 sampai dengan tahun 2015.

Tabel 8. Penggolongan Biaya Tetap dan Biaya Variabel

\begin{tabular}{lcccc}
\hline \multicolumn{2}{c}{ Biaya Tetap } & \multicolumn{4}{c}{ Tahun Produksi } \\
\cline { 2 - 5 } & $\mathbf{2 0 1 2}$ & $\mathbf{2 0 1 3}$ & $\mathbf{2 0 1 4}$ & $\mathbf{2 0 1 5}$ \\
\hline Biaya penyusutan & 1.229 .400 & 1.229 .400 & 1.229 .400 & 1.229 .400 \\
$\begin{array}{l}\text { Peralatan } \\
\text { Biaya }\end{array}$ penyusutan & & & & \\
Kendaraan & 8.437 .500 & 5.400 .000 & 8.437 .500 & 8.437 .500 \\
Biaya kredit Bank & 21.600 .000 & 21.600 .000 & 21.600 .000 & 21.600 .000 \\
Jumlah & 31.266 .900 & 28.229 .400 & 31.266 .900 & 31.266 .900 \\
\hline & & & & \\
Biaya Variabel & & & & \\
Biaya bahan baku & 3.100 .000 & 3.100 .000 & 3.700 .000 & 3.700 .000 \\
Upah tenaga kerja & 8.000 .000 & 8.000 .000 & 8.000 .000 & 8.600 .000 \\
Biaya pemasaran & 3.000 .000 & 6.200 .000 & 3.000 .000 & 3.000 .000 \\
Biaya kemasan & 6.500 .000 & 6.500 .000 & 5.572 .000 & 5.572 .000 \\
Biaya pemeliharaan & 2.160 .000 & 2.160 .000 & 2.160 .000 & 2.160 .000 \\
Biaya Bahan Bakar & 800.000 & 800.000 & 1.400 .000 & 1.400 .000 \\
Jumlah & 23.560 .000 & 26.760 .000 & 23.632 .000 & 24.432 .000 \\
Sumber: Data Primer, 2015. Diolah & & & \\
\hline
\end{tabular}




\begin{tabular}{|c|c|c|c|c|}
\hline \multicolumn{5}{|c|}{$\begin{array}{r}\text { Tabel 10. Rekapitulasi Break Even Point Penjualan Pupuk Kompos Toar } \\
\text { Organic Fertilizer untuk Produk Tunggal kemasan } 20 \text { kg }\end{array}$} \\
\hline Keterangan & 2012 & 2013 & 2014 & 2015 \\
\hline Biaya Tetap & 31.266 .900 & 28.229 .400 & 31.266 .900 & 31.266 .900 \\
\hline Biaya Variabel & 22.760 .000 & 25.960 .000 & 23.532 .000 & 24.152 .000 \\
\hline $\begin{array}{l}\text { Biaya Variabel per } \\
\mathrm{kg}\end{array}$ & 22.760 & 25.960 & 23.532 & 24.152 \\
\hline Harga Jual per unit & 60.000 & 60.000 & 68.000 & 68.000 \\
\hline $\begin{array}{l}\text { Total Produksi per } \\
\text { unit }\end{array}$ & 1.000 & 1.000 & 900 & 900 \\
\hline Penerimaan & 60.000 .000 & 60.000 .000 & 61.200 .000 & 61.200 .000 \\
\hline BEP (per kg) & 839 & 829 & 700 & 713 \\
\hline BEP (rupiah) & 50.376 .315 & 45.482 .384 & 47.620 .256 & 48.487 .684 \\
\hline Keuntungan & 8.514 .902 & 9.044 .404 & 13.274 .034 & 12.391 .227 \\
\hline
\end{tabular}

Sumber: Data Primer, 2015. Diolah

Tabel 11. Rekapitulasi Break Even Point Penjualan Pupuk Kompos Toar Organic Fertilizer untuk Sales Mix Produk

\begin{tabular}{lcccc}
\hline \multicolumn{1}{c}{ Keterangan } & $\mathbf{2 0 1 2}$ & $\mathbf{2 0 1 3}$ & $\mathbf{2 0 1 4}$ & $\mathbf{2 0 1 5}$ \\
\hline Biaya Total & 31.266 .90 & 28.229 .40 & 31.266 .900 & 31.266 .900 \\
Biaya Variabel & 0 & 0 & & \\
& 23.560 .00 & 26.760 .00 & 23.632 .000 & 24.432 .000 \\
Harga Jual Kemasan 5 Kg & 0 & 0 & & \\
Harga Jual Kemasan 20 Kg & 15.000 & 15.000 & 17.000 & 17.000 \\
Volume Produksi Kemasan 5 & 60.000 & 60.000 & 68.000 & 68.000 \\
Kg & 200 & 200 & 72 & 72 \\
Volume Produksi Kemasan & 950 & 950 & 882 & 882 \\
20 Kg & & & & \\
BEP (Unit) Kemesan 5 Kg & 172 & 169 & 60 & 61 \\
BEP (Unit) Kemesan 20 Kg & 816 & 807 & 735 & 750 \\
BEP (Keseluruhan) & 51.485 .09 & 50.955 .59 & 50.948 .183 & 52.042 .110 \\
& 8 & 6 & & \\
Penerimaan & 60.000 .00 & 60.000 .00 & 61.200 .000 & 61.200 .000 \\
Laba & 0 & 0 & & \\
\hline Sumbr: Data Primer, & 8.514 .902 & 9.044 .404 & 10.251 .817 & 9.157 .890 \\
\hline
\end{tabular}

Sumber: Data Primer, 2015. Diolah

Analisis Break Even PointPenjualan Pupuk Kompos Toar Organic Fertilizer

Dengan mengetahui total biaya tetap, biaya variabel per unit dan harga per unit, maka dapat diketahui pada volume produksi dan penjualan berapa impas atau pulang pokok dapat terjadi. Seperti halnya perusahaan besar, usaha-usaha kecil menengah juga dalam menjalankan usahanya berusaha meminimalisir biaya-biaya yang dibutuhkan agar memperoleh keuntungan yang sebesar-besarnya. Hasil dari penjualan diharapkan mampu menutupi biayabiaya operasional yang telah digunakan. Oleh karena itu, perusahaan perlu mengetahui tingkat produksi dan penerimaan minimum agar perusahaan tidak menderita kerugian tetapi juga belum menerima laba (Rahmawati, 2008).

Berikut adalah perkembangan BEP usaha pupuk kompos Toar Organic Fertilizer selama usaha ini berdiri yaitu tahun 2012, 2013, 2014 
dan 2015 dalam kemasan tunggal dan mix product.

1. Analisis Break Even Point untuk Produk

Tunggal Kemasan 5 kgdan 20 kg

Analisis BEP produk Tunggal adalah analisis yang digunakan untuk menguji dengan mengansumsikan seluruh pupuk kompos

Hasil perhitungan break even point menunjukkan impas produk per unit dan impas penjualan pada produk tunggal dan pada produk sales mix yang terjadi pada setiap tahun selama usaha mulai memproduksi telah berada di atas titik impas. Pada analisis titik impas penjualan secara keseluruhan pupuk kompos tertinggi pada usaha pupuk kompos Toar Organic Fertilizer selama periode empat tahun analisis terjadi pada tahun 2015 yaitu sebesar Rp. 52.042.110 dan pada tahun 2014 merupakan tahun terendah yaitu Rp. 50.948.183.

Semakin rendah titik impas penjualan maka semakin cepat perusahaan memperoleh laba. Dari hasil analisis break even point pada usaha ini maka usaha kecil menengah ini sudah melebihi keadaan titik impas. Hal ini berarti usaha mendapatkan keuntungan. Adapun keuntungan usaha tersebut dapat dilihat dari jumlah penerimaan dengan nilai break even point yang diperoleh dan keuntungan terbesar yang diperoleh usaha ini selama usaha ini berdiri yaitu pada tahun 2014 dan 2015, dimana total penerimaan pada tahun tersebut adalah $\mathrm{Rp}$. 61.200.000sedangkan hasil break even point dari data yang diperoleh adalah Rp. Rp. 50.948.183.

\section{KESIMPULAN DAN SARAN}

\section{Kesimpulan}

Berdasarkan hasil penelitian serta pembahasan yang telah diuraikan padabab sebelumnya, maka dapat diambil kesimpulan sebagai berikut : Produksi dan penerimaan Usaha Pupuk Kompos Toar Organic Fertilizer dalam keadaan Break Even Point dari segi penjualan dan jumlah produksi bahkan mengalami keuntungan. diproduksi dalam bentuk kemasan $5 \mathrm{~kg}$ dan $20 \mathrm{~kg}$.

2. Analisis Break Even Point untuk Produk Sales Mix

Analisis BEP untuk lebih darisatu produk adalah analisis yang digunakan untuk menguji seluruh pupuk kompos yang diproduksi.

\section{Saran}

Agar Usaha Pupuk Kompos Toar Organic dapat memperluas pemasaran sehingga keuntungaan yang diperoleh akan semakin meningkat dan mampu mempertahankan penjualan dan jumlah produk yang di produksi agar usaha ini dapat berjalan dengan baik dan mengalami peningkatan.

\section{DAFTAR PUSTAKA}

Anonyomus. 2004. SNI 01-3545-2004. Badan Standarisasi Nasional.

Cempaka, D. M. 2015. Analisis Break Even Point Penjualan Pupuk Organik. Jurnal Fakultas Pertanian Universitas Udayana, Bali.

Departemen Pertanian. Jumlah Kebutuhan dan Ketersedian Pertanian Organik di Indonesia. 2015, Indonesia.

IFOAM. 2005. Prinsip - prinsip Pertanian Organik. IFOAM General Assembly, 2005. Adelaide, Kementrian Pertanian, Indonesia.

Indriani, Y. H. 2013. Membuat Kompos secara Kilat. Penebar Swadaya, Depok.

Jumingan. 2008. Studi Kelayakan Bisnis. PT. Bumi Aksara, Jakarta.

Kamaludin. 2011. Manajemen Keuangan Konsep Dasar dan Penerapannya. Mandar Maju. Bandung.

Kasmir. 2010. Pengantar Manajemen Keuangan. Kencana Prenada Media Group. Jakarta 
Krismiaji dan Aryani . 2011. Akuntansi Manajemen Edisi Kedua. Sekolah Tinggi Ilmu Manajemen YKPN. Yogyakarta.

Murbandono, L. 2002. Membuat Kompos. Penebar Swadaya, Jakarta.

Musnawar, E. I. 2003. Pembuatan dan

Aplikasi Pupuk Organik Padat. Penebar Swadaya, Jakarta.

Nugroho, P. 2011. Panduan membuat Pupuk Kompos Cair. Pustaka Baru Press, Yogyakarta.

Nugroho, P. 2013. Panduan membuat Pupuk Kompos Cair II. Pustaka Baru Press, Yogyakarta.

Prasetyo, W. 2010. Analisis Break Even Point pada Industri Pengolahan Tebu di Pabrik Gula Mojo Kabupaten Sragen. Skripsi Fakultas Pertanian Universitas Sebelas Maret, Surakarta.

Rahmawati, 2008. Analisis Break Even Point pada Usaha Pengolahan Pucuk Daun Teh. Skripsi Fakultas Pertania Universitas Sebelas Maret, Surakarta.

Rangkuti, F. 2010. Teknik Membuat Perencanaan Bisnis dan Analisis Kasus. . Gramedia Pustaka Utama, Jakarta

Samryn, M. L. 2012. Akuntansi Manajemen Informasi Biaya untuk Mengendalikan Aktivitas Operasi dan Informasi. Kencana, Jakarta.

Sigit, S. 2002. Pemasaran Praktis Edisi Ketiga. BPFE. Jakarta.

Surjadi, L. 2013. Akuntansi Biaya. Indeks, Jakarta.

Subagyo, P. J. 2006. Metodologi Penelitiandalam Teori dan Praktek. Rineka Cipta, Jakarta.

Sujawerni, V. W. 2014. Metodologi Penelitian.
Pustaka Baru, Yogyakarta.

Sujarweni, V. W. 2015. Akuntansi Manajemen Teori dan Aplikasi. Pustaka Baru, Yogyakarta

Sutanto, R. 2002. Pertanian Organik. Kanisius, Yogyakarta.

Yuliarti, N. 2009. 1001 Cara Menghasilkan Pupuk Organik. Lily Publisher, Yogyakarta. 